Research Space

Journal article

Primary school students' perspectives on questions that bridge science and religion: findings from a survey study in England Billingsley, B., Abedin, M. and Nassaji, M.

"This is an Accepted Manuscript of an article published by Taylor \& Francis in British Educational Research Journal on 13th September 2019, available online: https://doi.org/10.1002/beri.3574 
Primary school students' perspectives on questions that bridge science and religion: findings from a survey study in England

\section{Berry Billingsley}

Manzoorul Abedin

Mehdi Nassaji

Faculty of Education, Canterbury Christ Church University, Canterbury, United Kingdom

Berry.billingsley@canterbury.ac.uk

Manzoorul.abedin@canterbury.ac.uk

Mehdi.nassaji@canterbury.ac.uk

Berry Billingsley is Professor in Science Education at the Faculty of Education, Canterbury Christ Church University. She is also the principal investigator of the LASAR (Learning about Science and Religion) research project.

Manzoorul Abedin is a LASAR Research Fellow at the Faculty of Education, Canterbury Christ Church University. He works in the primary education strand of the LASAR Project.

Mehdi Nassaji is a LASAR Research Fellow at the Faculty of Education, Canterbury Christ Church University, specialising in philosophy and quantitative research. 


\title{
Primary students' perspectives on questions that bridge science and religion: findings from a survey study in England
}

\begin{abstract}
This paper describes the development of a questionnaire to discover primary school students' perceptions of science, religion and the relationships between them on a range of topics that are known as Big Questions. The questionnaire was administered in 16 primary schools in England with over 750 students aged 10-11. The findings indicate that students in this age group have begun to consider how science and religion relate and that while there is a diversity of positions, a significant proportion perceived science and religion to conflict. Analysis of responses also indicated that primary school students' epistemic insight was limited in relation to their understanding of the nature of science and in particular, the idea that science has limitations. The basis and potential consequences of such views are considered and recommendations for teaching practice are presented together with ideas for future research. It is anticipated that the study will inform teachers and curriculum planners developing approaches and guidance materials in science and RE.
\end{abstract}

Key words: Primary science; science and religion; science classroom; student perceptions; nature of science; worldviews. 


\section{Introduction}

There are many big questions about life and the universe that can potentially fascinate and motivate today's students as they progress through school. We characterise Big Questions as questions on which both science and religion have something to say and as questions that concern the nature of reality and human personhood, such as, 'can a robot be a good friend?', 'why does the universe exist?' and 'to what extent are we each responsible for our actions?' (Authors 2018). The study we report in this paper was prompted by concerns about how schools manage students' expressed curiosity about Big Questions and their developing epistemic insight into ways that disciplines and other knowledge domains interact. Epistemic insight - or 'knowledge about knowledge' - refers to the attitudes and intellectual capacities required to appreciate how knowledge and scholarship work within and across subject boundaries (Authors, 2017). Ways to teach epistemic insight include drawing attention to the the distinctive ways that science and history formulate and conduct an enquiry on a topic on which both have something to say. It also includes exploring the strengths and limitations of science in the contexts of real world problems and multidisciplinary arenas. Thirdly it includes developing students' understanding of the relationships between science and religion - a particular focus in the current study.

The study is the first to develop and test a tool designed to investigate how primary school students reason about the natures of science and religion and the relationships between them. Students in Year 6 (10-11 years old) were asked to rate their level of agreement with each of a set of statements about science, religion, and how they 
relate. Students were also asked about their perceptions of whether and how these issues are addressed in school.

Alongside our circumspection that a Big Question can be a stimulus for teaching epistemic insight, we also surmised that pedagogical factors such as avoiding Big Questions in schools can instigate or sustain epistemic gaps and misperceptions. The basis for this concern derives from interview studies with teachers and students in secondary schools. One of the findings of that research was that some students had not considered the possibility that science and religion interact at all until prompted to do so during the research (Authors, 2016; 2013). In the discussion that follows, students' real names are replaced by pseudonyms. Christine (age 13) stated that:

"I've met religion, and I do science, but I've never had 'em both together, like, I never knew it could link in such a way."

[...] "I knew that people say that God makes the Earth sometimes, and some people say it's caused [by] the Big Bang..., but I didn't connect it, or link it in any way to do with science and religion" (Authors 2013: 1273).

There were also students who said that they would hold back a question in a science lesson if they felt it would be 'off-topic' or potentially religiously sensitive (Authors, 2013, 2016). Glenn (age 11) expressed the view that it would be inappropriate to ask questions that link science with religion "even though it would be interesting to find out what my science teacher actually thought". At another point in the interview, Glenn illustrated his interest in exploring interactions between what he understood to be scientific and religious ideas, by stating that:

Scientists say the more they understand about the Big Bang and creation, the closer they come to finding God. That kind of makes sense but... yeah, I also don't agree with it because I don't think he would leave a trail like that. I don't think he would leave like a big trail and no one find it. If he wanted us to know, we would know already. 
Interview comments like these prompted us to wonder how students in younger age groups characterise the relationships between science and religion and what support they receive from teachers. The aims of the current study were to develop and apply a survey instrument for primary schools, by drawing on the instruments that we have previously used in secondary schools. The study took place in England but the themes and findings are relevant internationally.

The paper is divided into the following sections: The first discusses research which has explored how science and religion relate in educational settings. The next section explains the research questions, context and methodology of the study. After a section on the findings, the last part of the paper offers conclusion and recommendations for teaching and curriculum design.

\section{The relationships between science and religion in schools}

The ways that people understand the relationships between science and religion are complex and one reason for this is that public perceptions vary with culture and historical period (Brooke, 1991). Research exploring whether students can consider multiple perspectives and form judgements about what to believe begins with younger age groups than those in our current study. There is a basis to say that preschool students can appreciate that people can have different and competing perspectives on a given topic (Wellman, 2014). However, when thinking about science and religion, we know that secondary school students frequently suppose that the choice to make is limited to one or the other (Author 1 et al, 2013). 
Research seeking to understand the prevalence of a conflict view in student perceptions has taken place in England, Australia, the United States and internationally (see for example Fulljames et al., 1991; Wilkinson, 2005; Author 1, 2016; Deniz et al., 2008; Author 1, 2004; Ha et al., 2012; Hansson and Redfors, 2007; Smith, 2010; Berkman and Plutzer, 2015; Barnes et al., 2017; Shipman et al., 2002). One of the key findings of these studies is that secondary school students frequently hold narrow and polarised positions on the natures of science and of religion (Ibrahim et al., 2009; Martin-Hansen, 2008; Smith and Scharmann, 2008). Surveys conducted in England and Germany revealed that secondary school students' tendency to see science and religion as conflicting is frequently associated with a conflation of science and scientism (see Konnemann et al., 2016; Astley and Francis, 2010). Scientism is a stance that includes believing that science is the only valid way to construct knowledge and that nothing exists beyond the material universe (Stenmark, 2001). Some scholars including Dawkins (2006) and Atkins (1995) write about the nature of science with what is arguably a 'scientistic' stance. Their views are a narrow group within a range of stances held by scientists, philosophers and other scholars. Some researchers have focused on the positions of students who react negatively to the teaching of evolution and the finding that some of these students hold a literalistic interpretation of the Biblical story of creation (Sanders and Ngxola, 2009; Reiss, 2013). This is of particular relevance in our context following the addition in 2014 of evolution to the primary school section of England's National science curriculum.

We have explained that secondary school students are tending towards a conflict view underpinned by polarised views of science and/or religion. We turn next to discuss some of the reasons why. To appreciate the arguments that are used to support 
different perspectives on how science and religion relate, students will need to appreciate that the natures of science and religion are not universally agreed (Author 2017; Konnemann et al., 2018). The position of the science curriculum in England (DfE, 2015) and internationally (Fensham, 2016) is that students should consider the power and limitations of science. In our curriculum framework we reference this insight by saying that students should appreciate that some questions are more amenable to science than others and that scientism is not a necessary presupposition of science. This epistemic insight is rarely taught although it is widely articulated in science curricula as an essential aspect of scientific literacy (Lederman et al., 2014; Hanley et al., 2014). Science teachers' resistance to discussing the power and limitations of science corresponds to a tendency to narrow the subject boundary in order to focus on building and assessing familiarity with established scientific ideas (Abrahams, 2017; Author 2010). As we noted earlier some of the secondary school students we interviewed commented that their science teachers avoided and discouraged questions that are sensitive and/or 'off-topic' (Authors, 2013). Further, students' perceptions of the epistemic authority of each teacher is divided by firm subject boundaries, placing another pressure on schools' capacities to develop students' epistemic insight (Authors, 2016). These pressures and boundaries support the circumspection that in secondary school students rarely analyse different types of questions including Big Questions to discern the extent to which they are amenable to scientific methods. This concern also finds basis in the comments by some RE teachers that students widely perceived science as a source of proven and limitless facts and that they were unable to influence students' ideas (Authors 2013). This is unfortunate as researchers have also made the case that unless they receive effective teaching, school students are unlikely to appreciate that there is a range of views and 
that science and religion are not necessarily incompatible (Reich, 1991;

Author 1 et al, 2013). Whereas at secondary level, students typically have specialist subject teachers, primary school teachers are likely to teach several subjects (Overton and Chatzichristodoulou, 2010; Aikenhead and Jegede, 1999). This prompted our current interest which is to ascertain the part that primary school education plays and whether and how this phase can do more to enrich student understanding given the pressures of entrenched subject compartmentalisation in secondary school.

\section{Context and Curriculum}

England has a multicultural population but the state religion is Christianity and the majority of those who say they have a faith say that this is Christianity (ONS, 2012). Most schools in England are not associated with a particular religion while a significant minority (about a third) of state schools are denoted as Church schools with a religious character. Our survey includes a number of questions that refer to Christianity and our data analyses and discussion make specific references to Christianity. This focus is in part reflective of the predominance of Christianity in the British population. There is also curricular guidance that in England Local Authorities must ensure that the agreed syllabus for their area is consistent with Section 375(3) of the Education Act 1996, which requires the syllabus to reflect that the religious traditions of Great Britain are in the main Christian whilst taking account of the teaching and practices of the other principal religions represented in Great Britain. RE is taught in most schools in England, including government-run ('public') schools (Schreiner, 2000). The subject is controlled through SACREs (locally-based Standing Advisory Councils for RE) or, in the cases of faith schools, the relevant faith communities. Academies, which are independent, state-funded schools, can in some 
cases develop their own RE syllabus but they also need to meet certain requirements. Most local curriculum designers draw on a non-statutory National Framework for RE which gives guidance on what should be covered.

The Church of England is not opposed to the theory of evolution and when Dr Rowan Williams who was then Archbishop of Canterbury was asked for his attitudes towards a creationist/literalistic reading of Genesis, he was reported by journalists as "emphatic in his criticism of creationism being taught in the classroom" (Bates, 2006). There are nonetheless some branches of Christianity and other faith traditions in England that advocate creationist positions and refuse evolution. The issue of what schools can and should teach is regularly debated in public and policy forums. A 2018 House of Commons Briefing paper called Faith Schools in England: FAQ states that current policy "prohibits the teaching of creationism as an evidence-based theory" and that creationism can be discussed "outside of science lessons" as "part of religious education lessons, provided that this does not undermine the teaching of established scientific theory" (Long and Bolton, 2018: 10-11).

\section{Research Questions}

The previous sections explained that studies in secondary schools reveal that students often hold narrow views of the natures of science and religion and that students frequently struggle to access teaching designed to broaden their understanding. This prompted our current study which seeks to discover whether students at the end of the primary phase have already formed a view of the power and limitations of science and whether by this point they have considered the question of how science and religion interact. The study was guided by the following research questions: 
RQ 1: How do primary school students characterise the general relationship between science and religion?

RQ 2: What are primary school students' perceptions of the power and limitations of science? What are their perceptions of the Christian account of creation?

RQ 3: What are primary school students' levels of familiarity with evolution?

RQ 4: What are primary school students' commitments to selected religious beliefs and to selected claims associated with science?

RQ 5: What is the prevalence of the view that science replaces religion?

RQ 6: What are primary students' perceptions of how questions and interactions concerning science and religion are addressed in school?

\section{Methodology}

The study employed a questionnaire which was administered to students in their last year of primary school at 16 schools. The steps taken to design the questionnaire for this study are shown in Figure 1: 
Figure 1: Development of survey

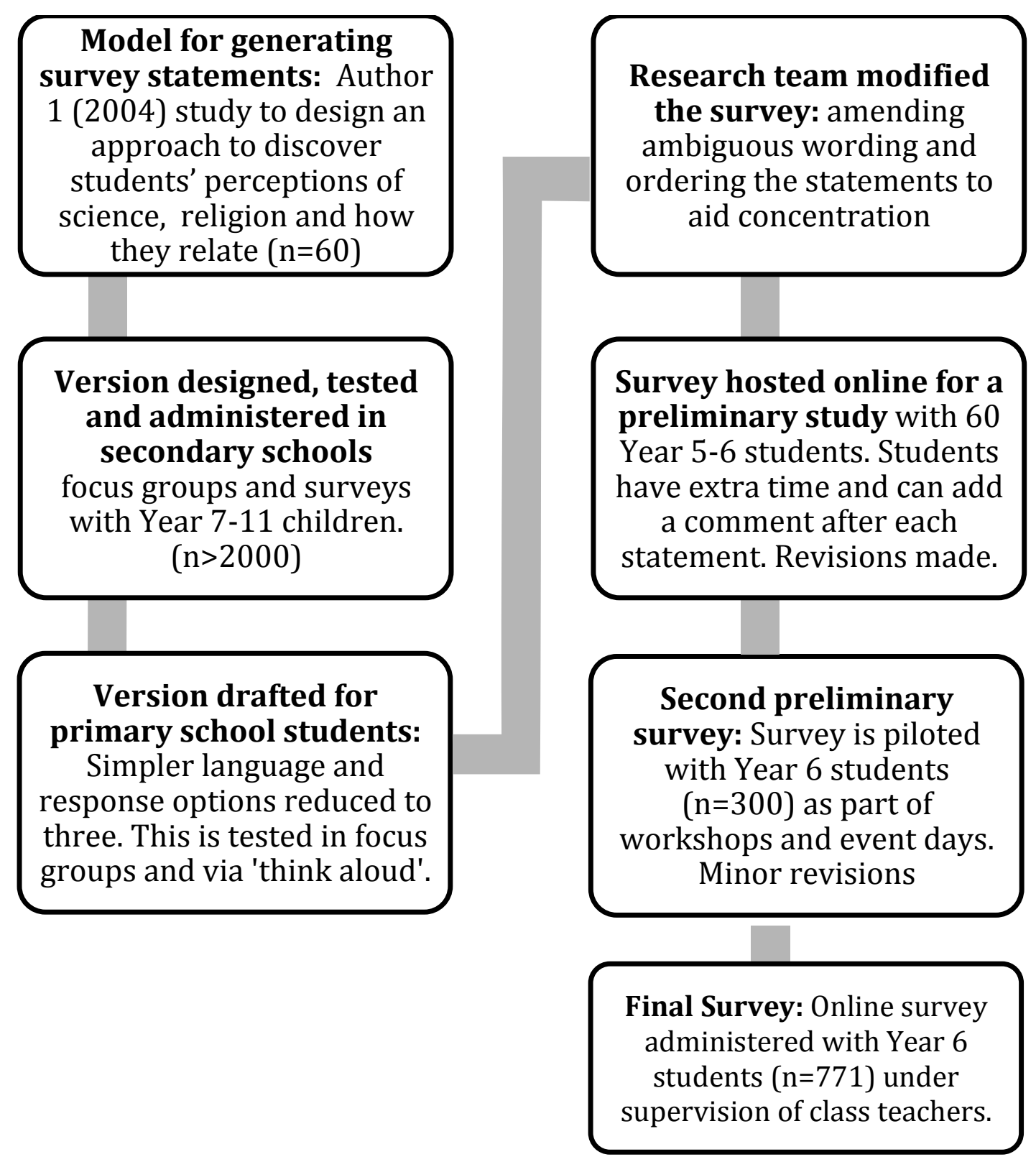


Preliminary work focused on tailoring and revising statements for a questionnaire for this age group. The statements were drawn from our previous studies of tertiary and secondary level students' views of the relationships between science and religion (Authors 2011; Author 1 2004; Authors 2015). Informed by the interviews and focus groups, we sought to focus for this study on issues where students commonly experience pressures and barriers in school and on identifying evidence of gaps and misperceptions in their epistemological understanding. Another factor directing the instrument design was our goal to have a questionnaire that could be presented to different age groups to look for similarities and differences across age groups. This meant we were open to including some statements that this age group find puzzling. Ethical considerations were another significant influence. To reduce the risk that students may be uncomfortable with answering certain questions, we regularly meet with an Advisory Board that includes child development specialists, ethicists, teachers and parents. Some topics such as the question of life after death are excluded on ethical grounds.

Working with two schools that did not participate in the final survey, we ran interviews and focus groups with students in the target age group. One technique we employed was to put cards on the table in front of an interviewee. Each card had a word in the survey and students picked up familiar words and explained their meanings. We also took groups of statements written on paper to individual students and focus groups of students and asked them to "think aloud," a technique which 
"requires the respondent to articulate what he is thinking as he goes about answering the question" (Bell, 2007: 467). These techniques established that the topics were familiar to the interviewees and led to revisions of some of the statements. We found that phrases like 'rule out' and 'fit together/ do not fit together' conveyed our intended meaning of mutual exclusivity better than 'in conflict with' and 'incompatible with'.

We then constructed a draft version and made it available online. One of the statements offered a general positive view of the relationship: 'Science and religion work together like friends'. For balance, another statement provided a general negative view of the relationship: 'Science makes it hard to believe in God (or a Greater Being).' There were also statements designed to explore students' ways of thinking about topics where some people perceive science and religion to contradict. The topics came from our previous work and are the origins of the universe and the origins of life, prayer, miracles and the existence of God (or a Greater Being). These topics are also discussed in the science-religion dialogue - a term widely used to refer to publications that explore how science and religion relate in general and on individual topics (Polkinghorne et al., 2014; Southgate, 2011; Ward, 2008; Murphy, 2014; Humphreys, 2003; Guessoum, 2015; Polkinghorne, 2013)

For each topic, we wrote a statement characterising what science is perceived to say or what religion is perceived to say or both. This produced statements such as 'The scientific view is that prayers cannot change what happens in the future' and 'Christianity teaches that the universe was created in six days (of 24 hours) followed by a day of rest'. Another group of statements sought to discover students' 
commitments to selected religious beliefs, for example, 'I believe the universe was created by God (or a Greater Being)'. For the topic of miracles we included 'I believe in miracles which break laws of nature' and a softer claim that, 'I believe miracles can happen as religion describes'. Another group of statements probed students' commitments to claims associated with science - 'humans evolved' and 'In science, theories become facts once they are proved'.

The next group of statements looked for the view that science replaces religion. These were, 'Science rules out Creation by God (or a Greater Being)' and the reverse statement that 'Science does not rule out Creation by God (or a Greater Being)'. A third statement in this group was 'You can believe both science and Creation by God (or a Greater Being)'. We surmised that some students agreeing to this third statement might hold both beliefs even while perceiving science and religion as contradictory.

The next step was to add tick-boxes for each statement to enable students to express levels of agreement. Some reviews of research have indicated a negative relationship between multiple response options and the quality of data collected from students and it seems that students from age 11 up are usually able to handle four or five options, while it is preferable to use three or four for younger respondents (Borgers et al., 2000). For this study we reduced the number of options for levels of agreement to three from five, where five is the number in our questionnaire for secondary students. Borgers et al. (2000: 18) model the way that students respond to survey statements using four steps which are:

(1) understanding and interpreting the question being asked; (2) retrieving the relevant information from memory; (3) integrating 
this information into a summarised judgment; (4) reporting this judgment by translating it to the format of the presented response scale.

The authors emphasise that questionnaires need to hold students' interest as if students become disengaged, they are likely to skip some of the steps and focus instead on giving answers that they think look appropriate. Holaday and TurnerHenson (1989) report that the use of longer statements is not necessarily a barrier if the structure and language is straightforward. Further, longer statements can provide memory cues that aid recall. In the current study, we surmised that some statements are long and also semantically complex for this age group. 'Science does not rule out Creation by God (or a Greater Being)' has a double negative which is discouraged by psychologists (Bell, 2007). The use of double negatives is to create a balance between positive and negatively worded statements and in this case the paired statement is 'Science rules out Creation by God (or a Greater Being)' The statement and its pair were initially shorter, 'Science rules out Creation' and 'Science does not rule out Creation' however in a trial run with these shorter versions, some students interpreted 'Creation' as a reference to creative work in school, an ambiguity that was resolved by the phrase, 'Creation by God (or a Greater Being)'.

To address our concern about the complexity of statements and the risk it creates for response errors we added an option for, "I don't understand the question" after the options for levels of agreement. In a trial run of the survey with 60 students, students were given extra time and were asked to put comments after each of their responses. Analysing students' responses and comments together indicated that the "I don't understand the question" option was an effective way to reduce response error and 
confirmed that the length of statements was not a key factor affecting students' understanding of the statements.

The final version consisted of 27 statements. Some additional questions asking students for their positions on religion and gender were placed at the end of the survey to avoid influencing how students responded to other questions. An introduction informed students that participation in the study is voluntary, that their responses would not affect their grades and that their names and the names of their schools would not be used in reports. In the lead up to the final implementation of the questionnaire in selected schools, we tested this version of the questionnaire with groups of school students from other schools participating in events organised by the project. This helped us to provide teachers with information about how long to allocate. We also constructed advice about what to say during and after the survey to students who ask about the issues raised. The statements are listed below with each research question. The number indicates where the statement appeared in the order in the questionnaire:

RQ 1: How do primary school students characterise the general relationship between science and religion?

14. Science makes it hard to believe in God (or a Greater Being)

17. Science and religion work together like friends

16. Science and religion disagree on so many things, they cannot both be true. 
RQ 2: What are primary school students' perceptions of the nature of science including their perceptions of the scientific position on claims associated with religion? What are their perceptions of the Christian view of creation?

25. In science, theories become facts once they are proved

21. The scientific view is that God does not exist

29. The scientific view is that God (or a Greater Being) does not exist

22. The scientific view is that it is impossible for miracles to happen which break laws of nature

23. Someone with a very scientific view cannot believe in miracles by God

24. The scientific view is that prayers cannot change what happens in the future

11. Christianity teaches that the universe was created in six days (of 24 hours) followed by a day of rest

RQ 3: What are primary school students' levels of familiarity with evolution?

5. I have heard of evolution

6. I know enough about evolution to explain it to a friend

RQ 4: What are primary school students' commitments to selected religious beliefs and to selected claims associated with science?

4. I believe in God (or a Greater Being)

7. I believe the universe was created by God (or a Greater Being)

12. I believe in miracles which break laws of nature

15. I believe miracles can happen as religion describes

19. Humans evolved

20. Humans did not evolve 
RQ 5: What is the prevalence of the view that science replaces religion?

8. Science rules out Creation by God (or a Greater Being)

9. Science does not rule out Creation by God (or a Greater Being)

10. You can believe both science and Creation by God (or a Greater Being)

RQ 6: What are primary students' perceptions of how questions and interactions concerning science and religion are addressed in school?

13. My teachers have talked about whether science and Creation fit together

26. I am likely to choose a career in science

27. I am interested in whether science and religion fit together

28. I am interested in whether science and people's cultural beliefs fit together 30. In school we have learnt about scientists who believe in God (or a Greater Being)

18. Many scientists believe in God (or a Greater Being)

\section{Sample and implementation}

The survey was completed by 771 students in 16 primary schools in England. We used convenience sampling to recruit the schools and reviewed the list at frequent points during the recruitment phase to ensure that we were engaging a mixture of school types. Four schools were Church schools, which compares favourably with the proportion of one-third Church schools among primary schools in England. One school was an independent boys' school and the rest were mixed state funded schools. The percentage of students eligible for free meals in each school is a factor that can be 
considered as a measure of poverty. In January 2018 , for all school types, $14 \%$ of pupils were eligible for and claiming free school meals (DfES, 2018). For the schools participating in our study, pupils eligible for free school meals ranged from $3.3 \%$ to $20 \%$, showing a variation of schools in the sampling. By drawing on the free school meals data for participating schools and the number of survey participants in each school, we calculated an indicative mean for our survey of students, which was $11 \%$. Analysis of the data indicates that 701 of the 771 students responded to the question 'how would you describe your position on religion (or your cultural beliefs)' and of these, $44 \%$ selected Christian, 13\% atheist, $9.0 \%$ Muslim, 2.0\% Hindu, 2.0\% Sikh, $1.0 \%$ Jewish, and $1.0 \%$ chose Buddhism. A further $7.0 \%$ selected the 'other' category and $21 \%$ of the respondents chose 'undecided'. By way of comparison in the last census of adults in Britain, $60 \%$ identified as Christian, $25 \%$ as no religion, $5.0 \%$ as Muslim, 3.0\% as other religious positions and 7.0\% chose not to respond to this question.

For each school, teachers and researchers worked together to identify an existing cohort of students who were not self-selecting, such as a year group or a library group. Students completed the survey using computers in school while supervised by a teacher. This supervision was another strategy to reduce self-selection. Missing data was less than $3.0 \%$ for most statements and up to $5.0 \%$ for some statements. We also sought teachers' help to ensure that our sample would have a range of intellectual levels and a balance across the full cohort of girls and boys. Analysis of the data indicated that $54 \%$ of respondents were boys and $46 \%$ were girls. Details of the participating schools and cohorts are given in Table 1: 
Table 1: Participating schools (names anonymised)

\begin{tabular}{|c|c|c|c|c|c|}
\hline & $\begin{array}{l}\text { Pupil } \\
\text { Surveyed }\end{array}$ & $\begin{array}{l}\% \text { of total } \\
\text { responses }\end{array}$ & $\begin{array}{l}\text { Region of } \\
\text { England }\end{array}$ & $\begin{array}{l}\text { Type of } \\
\text { school and } \\
\text { gender entry }\end{array}$ & $\begin{array}{l}\% \text { of } \\
\text { students } \\
\text { eligible } \\
\text { for free } \\
\text { meal }\end{array}$ \\
\hline $\begin{array}{l}\text { 1. Allerson } \\
\text { Preparatory } \\
\text { School }\end{array}$ & 64 & $8.3 \%$ & London & $\begin{array}{l}\text { Independent; } \\
\text { boys }\end{array}$ & $\begin{array}{l}\text { Not } \\
\text { recorded }\end{array}$ \\
\hline $\begin{array}{l}\text { 2. Brooklands } \\
\text { Primary School }\end{array}$ & 5 & $0.6 \%$ & $\begin{array}{l}\text { South } \\
\text { East }\end{array}$ & $\begin{array}{l}\text { Local } \\
\text { Authority } \\
\text { Maintained } \\
\text { (LM); mixed }\end{array}$ & $3.3 \%$ \\
\hline $\begin{array}{l}\text { 3. Dock Hill } \\
\text { Primary School }\end{array}$ & 57 & $7.4 \%$ & $\begin{array}{l}\text { South } \\
\text { East }\end{array}$ & LM; mixed & $5.7 \%$ \\
\hline $\begin{array}{l}\text { 4. Greyson } \\
\text { Academy }\end{array}$ & 61 & $7.9 \%$ & $\begin{array}{l}\text { South } \\
\text { East }\end{array}$ & $\begin{array}{l}\text { Academy } \\
\text { Sponsor Led; } \\
\text { mixed }\end{array}$ & $6.3 \%$ \\
\hline $\begin{array}{l}\text { 5. Hillside Primary } \\
\text { and Nursery } \\
\text { School }\end{array}$ & 72 & $9.3 \%$ & London & LM; mixed & $12 \%$ \\
\hline $\begin{array}{l}\text { 6. Ingleway } \\
\text { Primary School }\end{array}$ & 67 & $8.7 \%$ & $\begin{array}{l}\text { South } \\
\text { East }\end{array}$ & LM; mixed & $4.3 \%$ \\
\hline $\begin{array}{l}\text { 7. Juniper Primary } \\
\text { School }\end{array}$ & 27 & $3.5 \%$ & $\begin{array}{l}\text { South } \\
\text { East }\end{array}$ & LM; mixed & $14 \%$ \\
\hline $\begin{array}{l}\text { 8. Longfield Junior } \\
\text { School }\end{array}$ & 61 & $7.9 \%$ & $\begin{array}{l}\text { South } \\
\text { East }\end{array}$ & LM; mixed & $7.8 \%$ \\
\hline $\begin{array}{l}\text { 9. Milestone } \\
\text { Middle School }\end{array}$ & 112 & $15 \%$ & $\begin{array}{l}\text { West } \\
\text { Midlands }\end{array}$ & LM; mixed & $17 \%$ \\
\hline $\begin{array}{l}\text { 10. Norton } \\
\text { Primary School }\end{array}$ & 57 & $7.4 \%$ & $\begin{array}{l}\text { South } \\
\text { East }\end{array}$ & LM; mixed & $17 \%$ \\
\hline $\begin{array}{l}\text { 11. Oakford C } \\
\text { of E Primary } \\
\text { School }\end{array}$ & 25 & $3.2 \%$ & $\begin{array}{l}\text { South } \\
\text { East }\end{array}$ & LM; mixed & $\begin{array}{l}\text { Not } \\
\text { recorded }\end{array}$ \\
\hline $\begin{array}{l}\text { 12. St. Barnabas } \\
\text { C of E Primary } \\
\text { School }\end{array}$ & 26 & $3.4 \%$ & $\begin{array}{l}\text { South } \\
\text { East }\end{array}$ & $\begin{array}{l}\text { Voluntary } \\
\text { Aided (VA); } \\
\text { mixed }\end{array}$ & $20 \%$ \\
\hline $\begin{array}{l}\text { 13. St. } \\
\text { Christopher } \\
\text { Catholic Primary } \\
\text { School }\end{array}$ & 45 & $5.8 \%$ & $\begin{array}{l}\text { South } \\
\text { East }\end{array}$ & VA; mixed & $3.9 \%$ \\
\hline 14. St. Edith's & 4 & $0.5 \%$ & South & VA; mixed & $6.0 \%$ \\
\hline
\end{tabular}




\begin{tabular}{|c|l|l|l|l|l|}
\hline \multicolumn{2}{|c|}{$\begin{array}{l}\text { C of E Primary } \\
\text { School }\end{array}$} & & & East & \\
\hline $\begin{array}{c}15 . \quad \begin{array}{c}\text { Lydgate } \\
\text { primary School }\end{array} \\
\text { 16. St. Keyne C } \\
\text { of E School }\end{array}$ & 31 & $7.4 \%$ & $\begin{array}{l}\text { South } \\
\text { West }\end{array}$ & $\begin{array}{l}\text { Academy; } \\
\text { mixed }\end{array}$ & $19 \%$ \\
\hline Total & 771 & $100.0 \%$ & $\begin{array}{l}\text { South } \\
\text { East }\end{array}$ & VA; mixed & $2.8 \%$ \\
\hline
\end{tabular}

\section{Analysis}

To assist with statistical analysis the data were imported into a statistical analysis software package (SPSS). The aims of the analysis were to discover the general views of the relationship taken by this age group and their responses to selected topics.

\section{Findings}

\section{RQ 1: How do primary school students characterise the general relationship} between science and religion?

Table 2: Relationship between science and religion

\begin{tabular}{|l|l|l|l|l|}
\hline & Agree & $\begin{array}{l}\text { Neither agree } \\
\text { nor disagree }\end{array}$ & Disagree & $\begin{array}{l}\text { I don't } \\
\text { understand the } \\
\text { question }\end{array}$ \\
\hline $\begin{array}{l}\text { Science makes it hard to } \\
\text { believe in God (or a Greater } \\
\text { Being) }\end{array}$ & $45 \%$ & $24 \%$ & $27 \%$ & $4.0 \%$ \\
\hline $\begin{array}{l}\text { Science and religion work } \\
\text { together like friends }\end{array}$ & $17 \%$ & $33 \%$ & $45 \%$ & $5.0 \%$ \\
\hline $\begin{array}{l}\text { Science rules out Creation by } \\
\text { God (or a Greater Being) }\end{array}$ & $32 \%$ & $28 \%$ & $26 \%$ & $14 \%$ \\
\hline
\end{tabular}




\begin{tabular}{|l|l|l|l|l|}
\hline $\begin{array}{l}\text { Science does not rule out } \\
\text { Creation by God (or a Greater } \\
\text { Being) }\end{array}$ & $30 \%$ & $25 \%$ & $29 \%$ & $16 \%$ \\
\hline $\begin{array}{l}\text { You can believe both science } \\
\text { and Creation by God (or a } \\
\text { Greater Being) }\end{array}$ & $57 \%$ & $20 \%$ & $15 \%$ & $8.0 \%$ \\
\hline
\end{tabular}

In response to the positively worded statement 'Science and religion work together like friends', almost half of the respondents (45\%) disagreed, and only $17 \%$ of respondents agreed. The paired statement is 'Science makes it hard to believe in God (or a Greater Being)' where $45 \%$ agreed and $28 \%$ disagreed. The percentages of respondents who choose 'I don't understand the question' are very small for both statements at about $5.0 \%$. A third statement in this group looked at the interaction between students' general view of the relationship and how they perceived science and religion to interact on the topics. In response to, 'Science and religion disagree on so many things, they cannot both be true' we found that about a third of students agreed, while just under a third disagreed and a similar proportion chose the middle option. At the end of this set of statements of the survey, we invited students to add a comment if they wanted into a free textbox (there were three spaces in the survey that respondents could comment on statements). 56 of the 771 participants added comments to go alongside their Likert responses. The notion of science as factual and of religion as based on opinions or beliefs was present in many of the comments on these statements. One student wrote, "they are more or less opposite [...] science is fact and religion is belief' while another wrote, "Science is what we know; Religion is what we guess." Another comment was, 'it is always a constant battle for superiority ... hundreds of years ago religion was the main one but now science has proven facts to us that religion never could.' 
Students' comments were explored further using an analysis system developed by Author 1 et al. (2013) to analyse where some students were in their approaches to forming a view on the relationship. The categories in the 2013 typology were based on an interview study with 12 students in lower secondary school and were contradictory, negotiated, unknowable and unexplored. The first category corresponded to students who expressed a view that science and religion contradict; the second corresponded to students who explained that they are still seeking a view, the third category was for students who had hitherto not considered whether science and religion relate and the fourth was for students who said that they were not seeking a view of the relationship and there will never be a definite answer. In the interview sample of 12 , there were no students who said that science and religion are harmonious. Analysing the comments by primary school students revealed that these students are also at different points of decision-making in their approaches. For these students we added a category for comments that reflected 'harmony'.

Twenty three respondents made comments that indicated they perceived the relationship as 'contradictory'. These students also agreed with the statement 'Science and religion disagree on so many things, they cannot both be true'. One student commented that 'science and religion are only like rivals with different theories'. Another student commented that 'they never agree in million years'.

"'Negotiated' is a label we gave to the comments by nineteen students who said that science and religion appear to be conflicting but there could be a way to consider them as friends. Students' comments included: 'science and religion could work like 
friends' and 'they are not working like friends at the moment'. 'There are a few things that they can agree on'.

Comments by six students were categorised as expressions of 'Harmony'. One student commented that 'God uses science and evolution to create the universe'. All students in this category disagreed with the statement 'Science makes it hard to believe in God (or a Greater Being)' and no student agreed with the statement 'Science and religion disagree on so many things, they cannot both be true'. Moreover no student in this group disagreed with the statement that 'science and religion work together like friend'.

The approaches of a final group of eight students were categorised as 'unexplored' which refers to students who had not thought about the relationships between science and religion before. Two students in this category commented that they didn't understand the question when they are asked if science and religion work together like friends. One student stated that 'we have not learnt about this topic yet' and another respondent said she was not sure how to answer the question. The majority of respondents in this category chose the 'neither agree nor disagree' option for statements concerning the relationships between science and religion. For instance, seven out of eight respondents neither agreed nor disagreed with the statement 'Science and religion disagree on so many things, they cannot be both true'. Students' comments may or may not represent the pattern of approaches in the whole sample. Analysing the comments indicates, however, that across the sample, there are students who are at different points in their decision-making. 
We also ran a chi-square test to compare religious and non-religious school students' characterisation of the general relationship between science and religion. To run the test we eliminated the respondents who chose 'I don't understand the question'. The chi-square analysis revealed that there is an association between religiosity and the positive view of the relationship between science and religion. Below are the charts that show the differences between religious and non-religious groups for each statement for this research question. For all statements the differences were statistically highly significant.

Figure 2: Religious and non-religious students' characterisation of the general relationship between science and religion

\section{Science makes it hard to believe in God (or a Greater Being)}

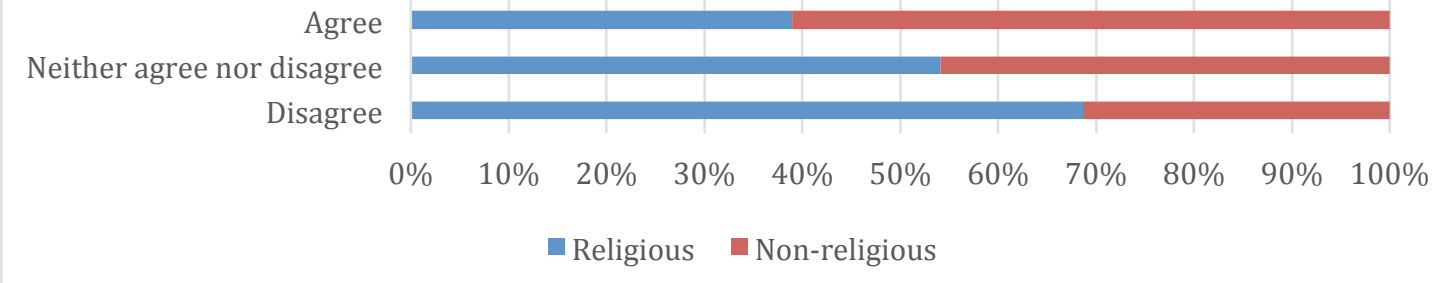

Science and religion work together like friends

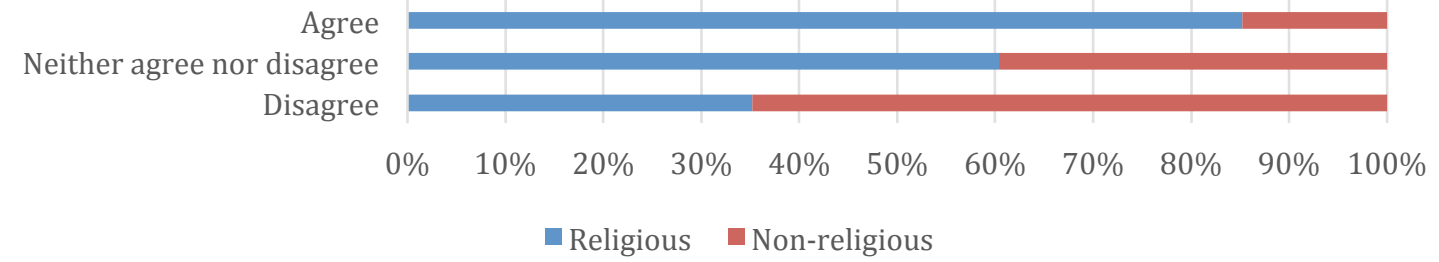




\section{Science and religion disagree on so many things, they cannot bot be true}

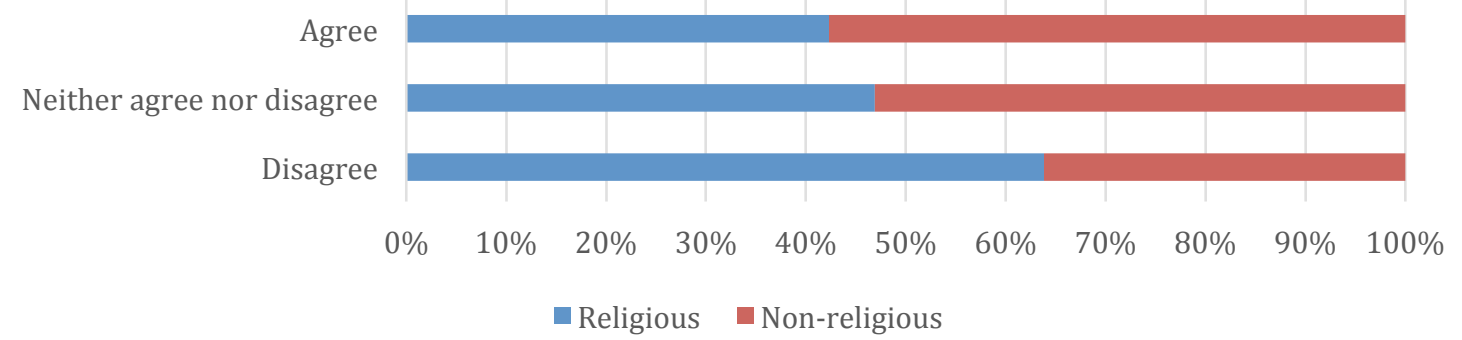

RQ 2: What are primary school students' perceptions of the nature of science including their perceptions of the scientific position on claims associated with religion? What are their perceptions of the Christian view of creation?

Table 3: Perception of the nature of science and scientific position on religion

\begin{tabular}{|l|l|l|l|l|}
\hline & Agree & $\begin{array}{l}\text { Neither } \\
\text { agree nor } \\
\text { disagree }\end{array}$ & Disagree & $\begin{array}{l}\text { I don't } \\
\text { understand } \\
\text { the question }\end{array}$ \\
\hline $\begin{array}{l}\text { In science, theories become facts } \\
\text { once they are proved }\end{array}$ & $68 \%$ & $17 \%$ & $6 \%$ & $11 \%$ \\
\hline $\begin{array}{l}\text { The scientific view is that God } \\
\text { does not exist }\end{array}$ & $37 \%$ & $31 \%$ & $26 \%$ & $6.0 \%$ \\
\hline $\begin{array}{l}\text { The scientific view is that God (or } \\
\text { a Greater Being) does not exist }\end{array}$ & $35 \%$ & $32 \%$ & $28 \%$ & $5.0 \%$ \\
\hline $\begin{array}{l}\text { The scientific view is that it is } \\
\text { impossible for miracles to happen } \\
\text { which break laws of nature }\end{array}$ & $35 \%$ & $27 \%$ & $24 \%$ & $14 \%$ \\
\hline \begin{tabular}{l} 
Someone with a very scientific \\
\hline
\end{tabular} & $21 \%$ & $31 \%$ & $36 \%$ & $12 \%$ \\
\hline
\end{tabular}




\begin{tabular}{|l|l|l|l|l|}
\hline $\begin{array}{l}\text { view cannot believe in miracles } \\
\text { by God }\end{array}$ & & & \\
\hline $\begin{array}{l}\text { The scientific view is that prayers } \\
\text { cannot change what happens in } \\
\text { the future }\end{array}$ & $44 \%$ & $28 \%$ & $24 \%$ & $4.0 \%$ \\
\hline
\end{tabular}

Most respondents (about 68\%) agreed that 'In science, theories become facts once they are proved'. These students' comments included that 'Science is factual' and 'I only believe science and logical answers and theories.' Over a third (37\%) of students agreed that 'the scientific view is that God does not exist', and about a quarter (26\%) disagreed. Some comments referred to 'proof' such as 'because we have no proof that [God] is real.'

More students disagreed (36\%) than agreed (21\%) that someone with a very scientific view cannot believe in miracles by God. $44 \%$ agreed that 'the scientific view is that prayers cannot change what happens in the future. One student commented, ‘... science is so advanced nowadays that there is an explanation for most things but it can still be possible to believe' and another asserted that, 'they have currently not got enough evidence or research to tell anyone anything.' More than a third (35\%) agreed with the statement that 'the scientific view is that it is impossible for miracles to happen which break laws of nature.'

We found that $41 \%$ of students agreed, 'Christianity teaches that the universe was created in six days (of 24 hours) followed by a day of rest.' For students who have identified themselves as Christians, agreement increased to 55\%. Students' comments indicated that some of those who disagreed might have been expressing the notion that their own view was different rather than commenting on whether the statement reflects the Christian position. For example one said, 'On earth, there is 
proof that it took 13 billion years to create the planet'. There were also comments by some students that this was the authoritative Christian stance but not the view they would take themselves. Examples were, 'It does, but just because they teach it doesn't mean that we have to believe it', 'Yes, we learnt about it!' and 'Christianity does teach that the world was created in 6 days but not every Christian believes it.' One student offered a nonliteral way to interpret the Biblical account saying, 'God's days are longer than earth's days.' $11 \%$ of students who identified themselves as Christians but did not understand the questions in this section indicated their limited learning opportunities in the RE lessons.

Table 4: Perception of religious position on Creation

\begin{tabular}{|l|l|l|l|l|}
\hline & Agree & $\begin{array}{l}\text { Neither } \\
\text { agree nor } \\
\text { disagree }\end{array}$ & Disagree & $\begin{array}{l}\text { I don't } \\
\text { understand } \\
\text { the question }\end{array}$ \\
\hline $\begin{array}{l}\text { Christianity teaches that the } \\
\text { universe was created in six days } \\
\text { (of } 24 \text { hours) followed by a day } \\
\text { of rest }\end{array}$ & $41 \%$ & $20 \%$ & $25 \%$ & $14 \%$ \\
\hline $\begin{array}{l}\text { Christianity teaches that the } \\
\text { universe was created in six days } \\
\text { (of 24 hours) followed by a day } \\
\text { of rest (Responses of children } \\
\text { who identified themselves as } \\
\text { Christian) }\end{array}$ & $55 \%$ & $19 \%$ & $15 \%$ & $11 \%$ \\
\hline
\end{tabular}

We ran a chi-square test to compare religious and non-religious school students' perceptions of the nature of science. To run the test we eliminated the respondents who chose 'I don't understand the question'. The chi-square analysis revealed that there is an association between religiosity and the perceptions of the nature of science. 
Below are the charts that show the differences between religious and non-religious groups for each statement about the nature of science. For all statements the differences were statistically highly significant.

Figure 3: Comparing religious and non-religious school students' perceptions of the nature of science

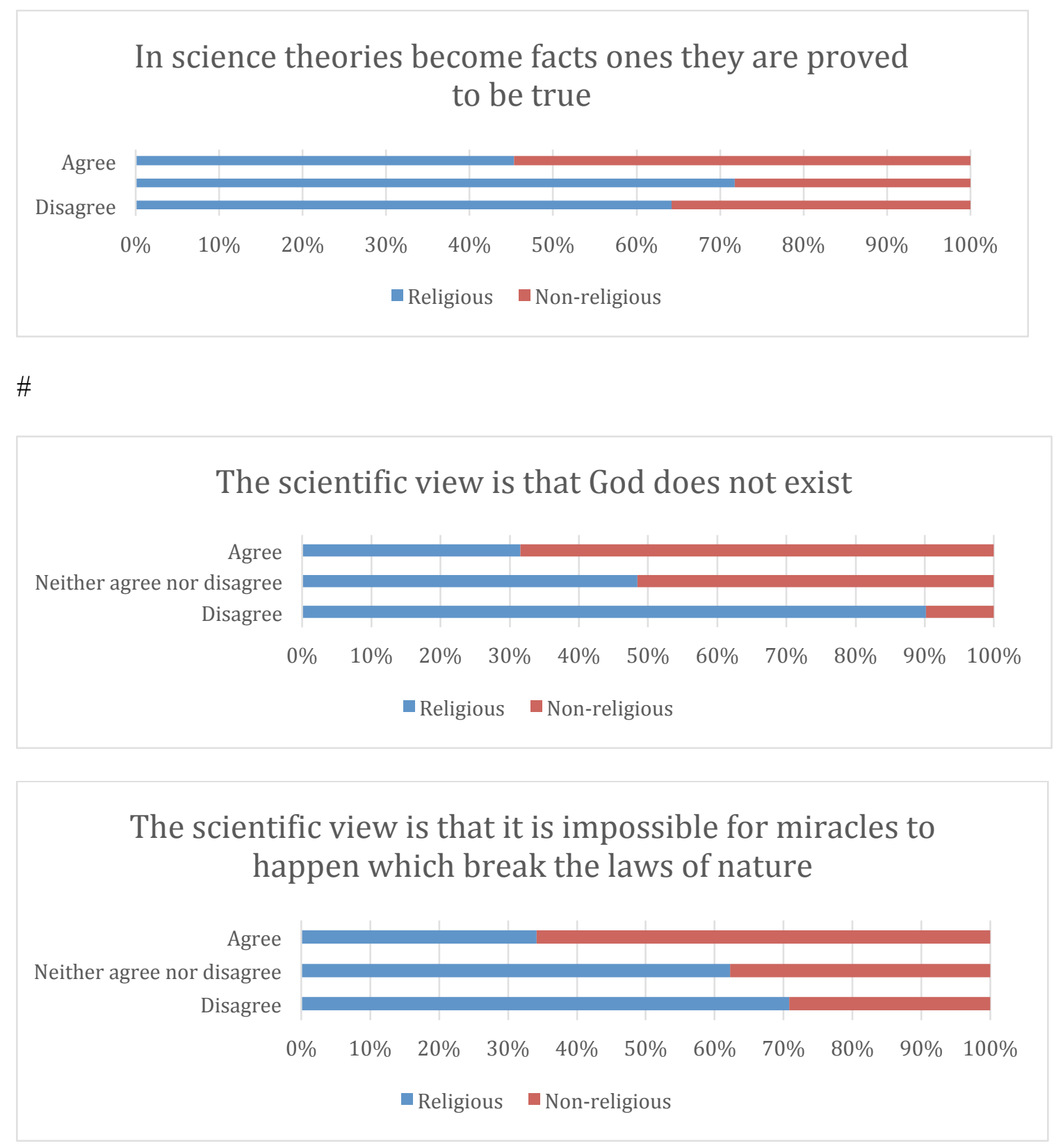




\section{Someone with a very scientific view cannot believe in miracles by God}
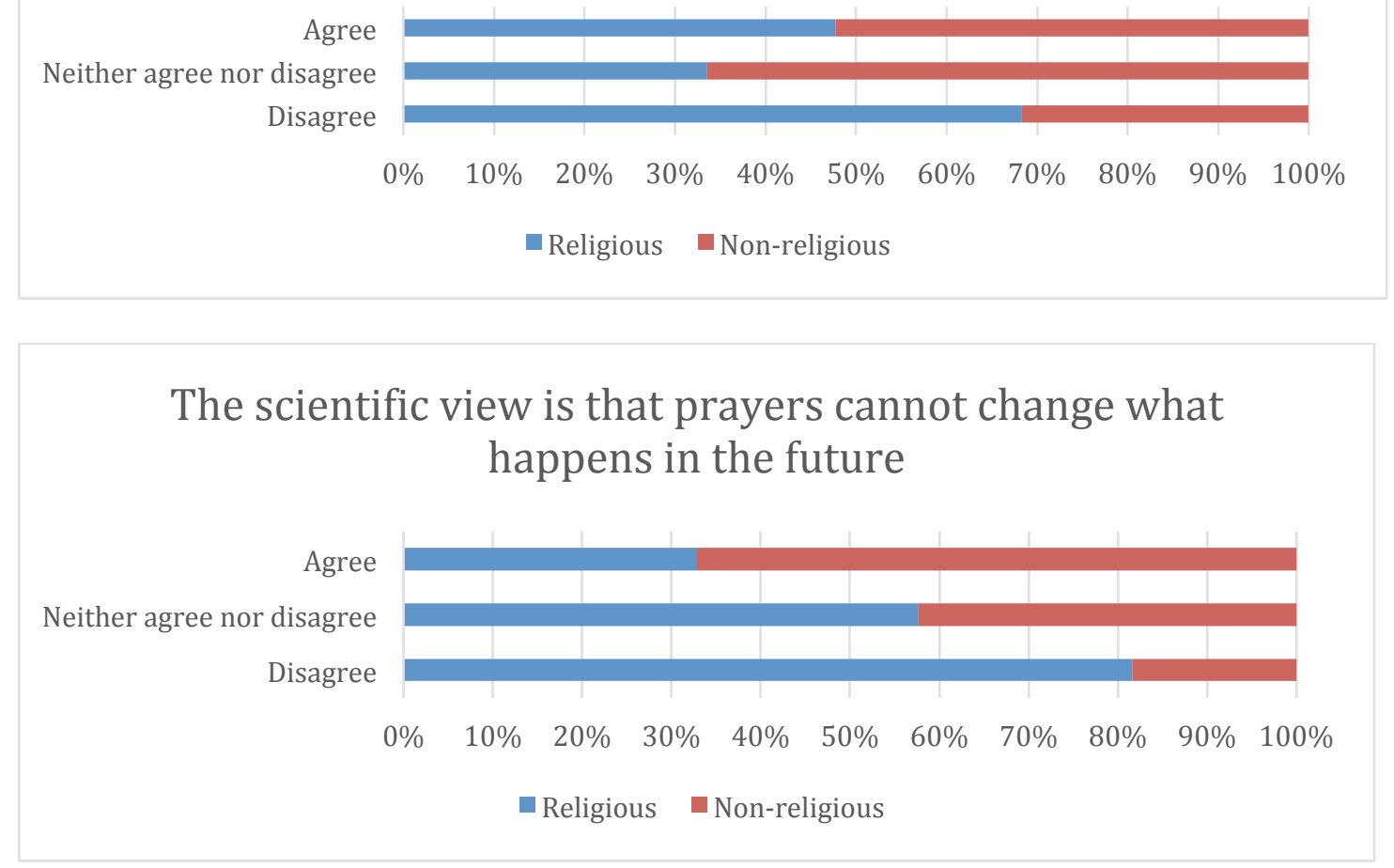

RQ 3: What are primary school students' levels of familiarity with evolution?

Most students (73\%) agreed that they 'have heard of evolution', but a much smaller proportion (43\%) of students agreed that 'I know enough about evolution to explain it to a friend'. In their comments, some students characterised evolution as a science topic that is addressed at school, "that was the last topic that we did"; some other comments reflected students' perceptions of what evolution says, including, 'Evolution is when something becomes something different like we evolved from chimpanzees or monkeys.'

Returning to the whole cohort, some of the comments that students wrote in response to statements expressing support for evolution emphasised their commitment to 
evolution as they understood it, such as, 'I believe in evolution and how the world performed over 150 years.' Over two thirds of students participating (70\%) agreed that 'Humans evolved' - a much higher proportion than the $43 \%$ of students who said they can explain evolution to a friend. Just over two thirds (67\%) disagreed with the reverse statement 'Humans did not evolve'. Among those who said they knew 'enough about evolution to explain it to a friend', agreement rose to $77 \%$ with the statement 'Humans evolved' and 76\% disagreed with the statement 'Humans did not evolve.' Some students who agreed that 'Humans evolved' made comments dismissing religion, for instance, 'The scientific version of how the world was created is so much more believable than the religious version,' which has 'no scientific evidence.' Another student, who highlighted the notion of proof, said 'evolution is real because we have got scientific evidence like fossils. We also looked at the correlation for 'humans evolved' and 'humans did not evolve', which shows Spearman correlation: $\mathrm{r}=-0.873, \mathrm{p}<0.001$.

Table 5: Perception on evolution

\begin{tabular}{|l|l|l|l|l|}
\hline & Agree & $\begin{array}{l}\text { Neither } \\
\text { agree nor } \\
\text { disagree }\end{array}$ & Disagree & $\begin{array}{l}\text { I don't } \\
\text { understand } \\
\text { the question }\end{array}$ \\
\hline I have heard of evolution & $73 \%$ & $9.0 \%$ & $12 \%$ & $6.0 \%$ \\
\hline $\begin{array}{l}\text { I know enough about evolution to } \\
\text { explain it to a friend }\end{array}$ & $43 \%$ & $19 \%$ & $33 \%$ & $5.0 \%$ \\
\hline Humans evolved & $70 \%$ & $14 \%$ & $9.0 \%$ & $7.0 \%$ \\
\hline Humans did not evolve & $11 \%$ & $15 \%$ & $67 \%$ & $7.0 \%$ \\
\hline
\end{tabular}




\section{RQ 4: What are primary school students' commitments to selected religious beliefs and to selected claims associated with science?}

In this section we firstly present a picture of students' religious commitments and then use crosstabs to explore instances where students believe that science holds a contradictory position to their own. We noted that $58 \%$ of students identified themselves as religious and that $54 \%$ of the total cohort ascribed to one of the Abrahamic religions (Christianity, Judaism and Islam). A smaller proportion of $45 \%$ agreed with the statement 'I believe in God (or a Greater being)' and a still smaller proportion of $33 \%$ agreed with the statement 'I believe the universe was created by God (or a Greater Being)' while 43\% disagreed.

In the case of belief in God, the proportion agreeing (45\%) is higher than those disagreeing (26\%). For belief in God creating the universe, the level of agreement $(33 \%)$ is lower than disagreement $(43 \%)$. The proportion who indicated they did not understand the question is low for each of these statements. Also there is a strong correlation between them with $\mathrm{r}=0.762, \mathrm{p}<0.001$. Students who believe that God created the universe also believe in God, however those who believe in God do not necessarily believe that God created the universe.

Just under a third (31\%) of the respondents agreed that they 'believe in miracles which break laws of nature' and about the same proportion (33\%) disagreed. Just over $35 \%$ of the students agreed that, 'I believe miracles can happen as religion describes', while about a third of the respondents disagreed with this position. More than a third of the students agreed with the statement that 'the scientific view is that it is impossible for miracles to happen which break laws of nature.' 
Table 6: Commitment to religion

\begin{tabular}{|l|l|l|l|l|}
\hline & Agree & $\begin{array}{l}\text { Neither } \\
\text { agree nor } \\
\text { disagree }\end{array}$ & Disagree & $\begin{array}{l}\text { I don't } \\
\text { understand } \\
\text { the question }\end{array}$ \\
\hline $\begin{array}{l}\text { I believe in God (or a Greater } \\
\text { Being) }\end{array}$ & $45 \%$ & $28 \%$ & $26 \%$ & $1.0 \%$ \\
\hline $\begin{array}{l}\text { I believe the universe was created } \\
\text { by God (or a Greater Being) }\end{array}$ & $33 \%$ & $24 \%$ & $43 \%$ & $0.0 \%$ \\
\hline $\begin{array}{l}\text { I believe in miracles which break } \\
\text { laws of nature }\end{array}$ & $31 \%$ & $24 \%$ & $33 \%$ & $12 \%$ \\
\hline $\begin{array}{l}\text { I believe miracles can happen as } \\
\text { religion describes }\end{array}$ & $35 \%$ & $24 \%$ & $33 \%$ & $8.0 \%$ \\
\hline $\begin{array}{l}\text { I believe that prayers can change } \\
\text { what happens in the future }\end{array}$ & $34 \%$ & $23 \%$ & $41 \%$ & $2.0 \%$ \\
\hline
\end{tabular}

Further analysis indicated that among students who believe in God or a Greater Being, just under a fifth (18\%) also agreed that, 'the scientific view is that God (or a Greater Being) does not exist'. Among students who believed that 'the universe was created by God (or a Greater Being)' about a quarter (26\%) agreed that 'Science rules out Creation by God (or a Greater Being)'. Of students who 'believe in miracles which break laws of nature', a quarter (25\%) agreed that 'the scientific view is that it is impossible for miracles to happen which break laws of nature.' In addition, a quarter $(25 \%)$ of students who believe miracles can happen as religion describes agreed 'someone with a very scientific view cannot believe in miracles by God.' Of students who believe that prayers can change what happens in the future, $24 \%$ agreed with 'the scientific view is that prayers cannot change what happens in the future.'

\section{RQ 5: What is the prevalence of the view that science replaces religion?}


Two statements explored the notion that 'science trumps religion' within the topic of origins. In response to the statement 'Science rules out Creation by God (or a Greater Being),' about a third of the respondents (32\%) agreed. Just over a quarter of students disagreed with this statement and $28 \%$ opted for the middle position (see Table 2). Comments entered into the survey illustrate some students' reasoning. One wrote: 'I believe in the big bang theory because I feel God wasn't invented at that time' while another wrote that 'science does not rule out Creation [...] If the big bang did occur, it must have been triggered by something.' Another wrote, 'I think there is some sort of similarity or some sort of mix'.

As we noted previously, a perception that two ideas or claims contradict is not necessarily a sufficient reason for students in this age group to reject one or the other. Here we notice that of students who agreed that 'You can believe both science and Creation by God (or a Greater Being)', almost a third (31\%) also agreed that 'the scientific view is that God (or a Greater Being) does not exist'. Students' comments include 'You can still believe in God even though we have no proof.' Looking at the reverse statement 'Science does not rule out Creation by God (or a Greater Being)', that appeared later in the survey, 30\% agreed and 29\% disagreed which appears to be consistent with the findings above. The Spearman coefficient for this pair of statements, $r=-0.683, p<0.001$ indicates a good correlation. The percentages of students responding "I don't understand the question" is $14 \%$ and $16 \%$ respectively are higher than for other questions in the survey and higher than for the statement about believing both (8\%).

We ran a chi-square test to compare religious and non-religious school students' prevalence of the view that science replaces religion. To run the test we eliminated the 
respondents who chose 'I don't understand the question'. The chi-square analysis revealed that there is an association between religiosity and the prevalence of the view that science replaces religion. Below are the charts that show the differences between religious and non-religious groups for each statement about the prevalence of science. For all statements the differences were statistically highly significant.

Figure 4: Comparing religious and non-religious school students' prevalence of the view that science replaces religion

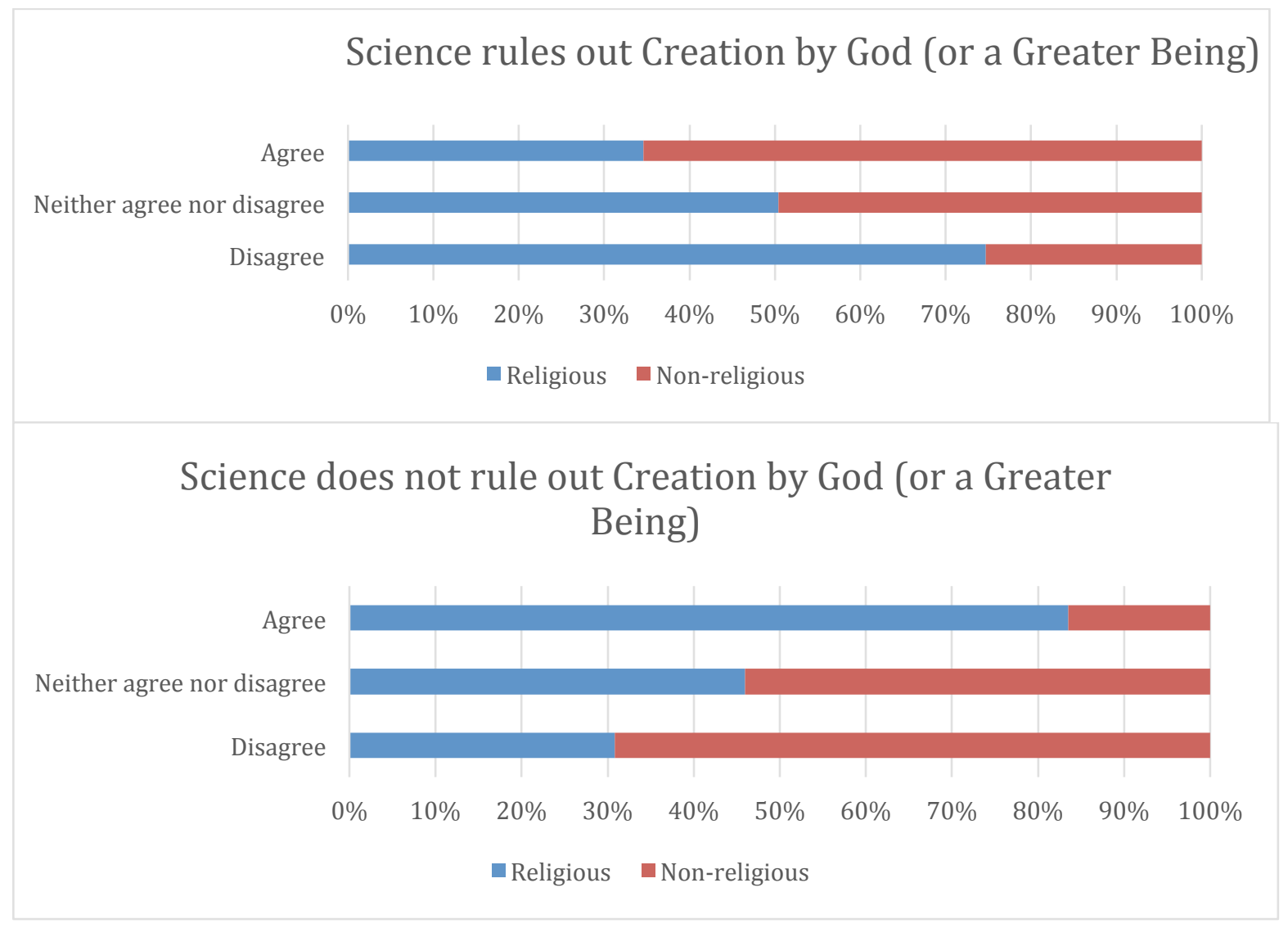




\section{You can believe both science and Creation by God (or a Greate being)}

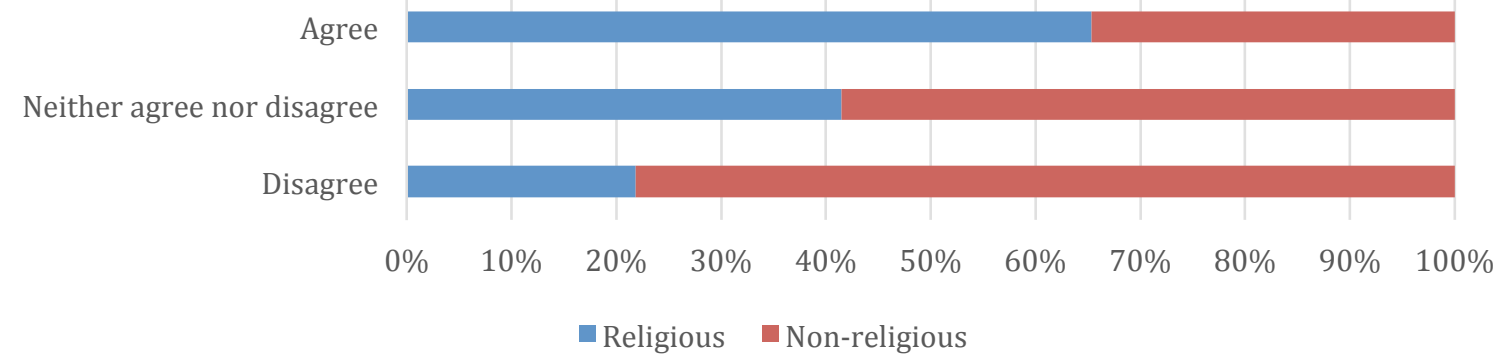

RQ 6: What are primary students' perceptions of how questions and interactions concerning science and religion are addressed in school?

Two fifths (41\%) of students participating disagreed that 'my teachers have talked about whether science and Creation fit together'; about half agreed (47\% and 46\% respectively) with the statements - 'I am interested in whether science and religion fit together' and 'I am interested in whether science and people's cultural beliefs fit together'. Just under a quarter (24\%) of students participating agreed that they are 'likely to choose a career in science' while $44 \%$ disagreed with this statement. Among students who believe in God $(n=338)$ and those who do not or are uncertain $(n=412)$, the proportions of students likely to choose a career in science are similar. We found that $22 \%$ of students who believe in God and $24 \%$ of those who do not are 'likely to choose a career in science'. Some students who indicated that they were not likely to work in science commented that they found science too 'difficult' or 'not [their] favourite' while others indicated that they 'could change [their] mind in the future.' Among students who believe in God and believe that 'the scientific view is that God (or a Greater Being) does not exist', 21\% agreed that they are 'likely to choose a career in science'. 
Just over a quarter (27\%) of the students agreed with the statement that 'many scientists believe in God (or a Greater Being)' while nearly a quarter (23\%) disagreed. However, the majority of the respondents (44\%) opted for 'neither agree nor disagree'.

The comments by students who agreed that scientists believe in God included, 'some scientists are religious' and 'some scientists can believe that God does exists'. However, we noted that many students were unsure or as in this case, indicated, 'I have never really met a scientist so I don't know.' There were similar comments in response to the statement 'In school we have learnt about scientists who believe in God (or a Greater Being)' in which more than half of the respondents, 59\%, disagreed, while $22 \%$ agreed.

Table 7: Perceptions of how questions and interactions concerning science and religion addressed in school

\begin{tabular}{|l|l|l|l|l|}
\hline & Agree & $\begin{array}{l}\text { Neither } \\
\text { agree nor } \\
\text { disagree }\end{array}$ & Disagree & $\begin{array}{l}\text { I don't } \\
\text { understand } \\
\text { the question }\end{array}$ \\
\hline $\begin{array}{l}\text { My teachers have talked about } \\
\text { whether science and Creation fit } \\
\text { together }\end{array}$ & $31 \%$ & $20 \%$ & $41 \%$ & $8.0 \%$ \\
\hline $\begin{array}{l}\text { I am likely to choose a career in } \\
\text { science }\end{array}$ & $24 \%$ & $29 \%$ & $44 \%$ & $3.0 \%$ \\
\hline $\begin{array}{l}\text { I am interested in whether science } \\
\text { and religion fit together }\end{array}$ & $47 \%$ & $21 \%$ & $28 \%$ & $4.0 \%$ \\
\hline $\begin{array}{l}\text { I am interested in whether science } \\
\text { and people's cultural beliefs fit } \\
\text { together }\end{array}$ & $46 \%$ & $25 \%$ & $20 \%$ & $9.0 \%$ \\
\hline $\begin{array}{l}\text { In school we have learnt about } \\
\text { scientists who believe in God (or } \\
\text { a Greater Being) }\end{array}$ & $22 \%$ & $15 \%$ & $59 \%$ & $4.0 \%$ \\
\hline
\end{tabular}




\begin{tabular}{|l|l|l|l|l|}
\hline $\begin{array}{l}\text { Many scientists believe in God } \\
\text { (or a Greater Being) }\end{array}$ & $27 \%$ & $44 \%$ & $24 \%$ & $5.0 \%$ \\
\hline
\end{tabular}

\section{Gender and perspectives on questions that bridge science and religion}

Previous research has indicated that gender may influence attitudes to thinking about Big Questions that bridge science and religion (Authors, 2017). The study described in this paper does not have the capacity to address this research question in depth but as an exploratory exercise, we compared the differences between girls and boys on all the statements reported in this paper. The differences were usually not statistically significant when we ran chi-square test. The only statistically significant differences were for the statements about the belief in God and miracles: 
Table 8: Gender and perspectives on questions that bridge science and religion

\begin{tabular}{|c|c|c|c|c|}
\hline \multicolumn{5}{|c|}{ I believe in God (or a Greater Being) $\mathrm{p}=0.002$} \\
\hline & & Girls & Boys & \\
\hline \multirow{3}{*}{$\begin{array}{l}\text { I believe in God (or a Greater } \\
\text { Being) }\end{array}$} & Agree & $49 \%$ & $51 \%$ & \\
\hline & Neither agree nor disagree & $52 \%$ & $48 \%$ & \\
\hline & Disagree & $36 \%$ & $64 \%$ & \\
\hline \multicolumn{2}{|l|}{ Total } & $46 \%$ & $54 \%$ & \\
\hline \multicolumn{5}{|c|}{ I believe in miracles which break laws of nature $p<0.000$} \\
\hline & & Girls & Boys & \\
\hline \multirow{3}{*}{$\begin{array}{l}\text { I believe in miracles which } \\
\text { break laws of nature }\end{array}$} & Agree & $39 \%$ & $61 \%$ & \\
\hline & Neither agree nor disagree & $58 \%$ & $42 \%$ & \\
\hline & Disagree & $42 \%$ & $58 \%$ & \\
\hline \multicolumn{2}{|l|}{ Total } & $45 \%$ & $55 \%$ & \\
\hline \multicolumn{5}{|c|}{$\begin{array}{l}\text { The scientific view is that it is impossible for miracles to happen which break laws } \\
\text { of nature } p<0.000\end{array}$} \\
\hline & & Girls & Boys & \\
\hline \multirow{3}{*}{$\begin{array}{l}\text { The scientific view is that it is } \\
\text { impossible for miracles to } \\
\text { happen which break laws of } \\
\text { nature }\end{array}$} & Agree & $39 \%$ & $61 \%$ & \\
\hline & Neither agree nor disagree & $55 \%$ & $45 \%$ & \\
\hline & Disagree & $37 \%$ & $63 \%$ & \\
\hline \multicolumn{2}{|l|}{ Total } & $43 \%$ & $57 \%$ & \\
\hline
\end{tabular}

One way to explain these findings would be to say that girls are more inclined to perceive the nature of reality as open to miracles and less inclined to see existing scientific patterns (laws) as binding. Further research could include an interview study to discover in more depth how students are responding to the statements and possibilities. 


\section{Discussion}

This study began by explaining a construct, epistemic insight, and drawing on work in secondary schools to emphasise the value of giving students opportunities to ask and explore Big Questions and to examine the natures of science and religion and the relationships between them. The findings of this research give a basis to say that a significant proportion of primary school students are curious about Big Questions and about how science and religion relate. Findings also indicate that by the end of primary school, many of the conceptualisations, attitudes and reasoning in secondary school students' perceptions about science and religion are beginning to be expressed. A perception of science and religion as conflicting is present to an extent in the perceptions and comments by this age group. A third of the students participating perceive that science and religion are mutually exclusive and almost half of the total cohort agree that science makes it hard to believe in God (or a Greater Being). Within a mixture of types of comments, there are references to a 'warfare' model. A third of students agreed with the statement that science has ruled out the possibility of creation by God. A large proportion of students in this age group are not fixed in their perceptions of science and religion or their views of the relationship. One indication of this is the weak correlation for paired statements and another is that their comments are frequently qualified by terms such as, 'I am not sure' and 'people can change their minds'. Detailed analysis of comments revealed examples of students at many points in the decision making process. In contrast, surveys and interview studies with older students and their RE teachers suggests that by upper secondary school, students are frequently entrenched in the view that science and religion are 'either/or' and that science is built around facts while religion consists of opinions (Author 1 et al., 2014). 
The findings of this study indicate that some primary school students perceive science and religion to take conflicting positions but do not see this as a reason to reject either. This stance is also taken by some older students - and we have previously reported finding that some students aged 14 chose to manage apparently incompatible positions rather than make a choice between them (Author 1, 2013). We note too that similar proportions of religious students and non-religious students indicate that they are considering a career in science. This said, students' positions are emerging and tentative and we support a call to ensure that there are learning opportunities for primary and secondary school students to consider the distinctive natures of science and religion. Learning about the nature of science could also include comparing science with disciplines like history in the humanities when they come together to address cross-discipline topics.

Turning to methodological issues, the response rate varies from statement to statement but does not tend to decrease overall during the survey. This is one indication that the survey is holding students' attention. We have noted the issue of response error and in particular that some students may have confused the categories underpinning the survey - where students were asked in this survey to answer 'on behalf of science' (what does science say), 'on behalf of religion' (what does religion say) as well as giving their own beliefs. Students' comments informed our understanding of how they interpreted the statements and we recommend including boxes for comments as part of the design.

One of the motivations for this study was to discover where students are likely to have gaps and misperceptions in their epistemological understanding (epistemic insight) and this helps to explain our choice of a survey. The survey is probing students' 
perceptions of how science and religion interact - if at all - on a range of topics. Interviews and focus groups informed the selections of positions that were offered in this survey. The need to constrain the length of the survey means that it only offers a few of the many ways of conceptualising each of science, religion and how they relate and this is one of its many limitations. The findings of this kind of research can inform curriculum design and help teachers with where to start. This said, it is important that in each setting, students' contexts and interests are taken into account and that students' individual questions and interests are addressed. Our preliminary work indicates that filling in the survey prompts some students to consider for the first time the possibility that there is an interaction. We see it as important to ensure that teachers supervising the survey are equipped with ways to develop students' curiosity and respond to their questions if these arise as a result of taking part in the survey.

\section{Conclusion and Further Research}

Students are naturally curious and in schools and beyond they are puzzled by questions that do not fit neatly in subject boundaries. The opportunity and challenge for teachers and educators is to provide students with an education that nurtures their curiosity and develops their capacities to be enquiring in ever more scholarly ways. The value and importance of examining the nature of science alongside other disciplines and ways of knowing is neglected and underexplored in school education in England (Sandoval, 2016). At the same time, exploring the nature of science in real world contexts and multidisciplinary arenas is one of the ways to help children to see that science connects with questions that interest them. We have proposed a framework to accompany the existing curriculum in England with objectives for epistemic insight for each of the key stages presented as a progression from age 5 to 
16. Within this framework one category of objectives is focused on the science classroom. There is a tendency in science teaching to prioritise scientific content knowledge over epistemology (Abrahams, 2017). Our research is contextualised by a wider call for schools to strengthen students' epistemic insight by exploring the nature of science in real world contexts and multidisciplinary arenas (see for example Billingsley and Hardman, 2017; Konnemann et al., 2018; Erduran et al., 2018). We recommend that students begin in lower primary school by learning about the characteristics of science. In upper primary school, we advise that they strengthen their understanding of the distinctive nature of scientific enquiry compared with other types of enquiry and their appreciation that some methods are more scientific than others. Drawing on the findings of this study and on research that reveals the pressures that apply in the secondary school context, we argue that primary school students would benefit from opportunities to talk about the similarities and differences between two disciplines such as science and history - as a foundation for learning in secondary school why some questions are more amenable to science than others. In upper secondary school, our guidance concords with the current science curriculum in England that students learn about the power and limitations of science (DfE, 2015). We also support the case presented in some other studies that at this level, students should appreciate the contentious natures of the boundaries around science and other areas of knowledge that they study (see for example Foster, 2013; Kötter and Hammann, 2017).

We also make the case that students would benefit from working with examples of Big Questions with a view to learning about the distinctive methodologies and insights that science, religion and other ways of knowing afford. The discipline wheel is one of the tools we have devised for workshops with school students and initial 
teacher education students in the primary context, designed to teach epistemic insight. There are two versions - one version of the wheel has a number of disciplines around the outside and a space for the teacher or student to put a question in the centre; another version is left blank for teachers or students to fill in the disciplines and areas of knowledge that they would like to include (see Figure 5).

Figure 5: The discipline wheel

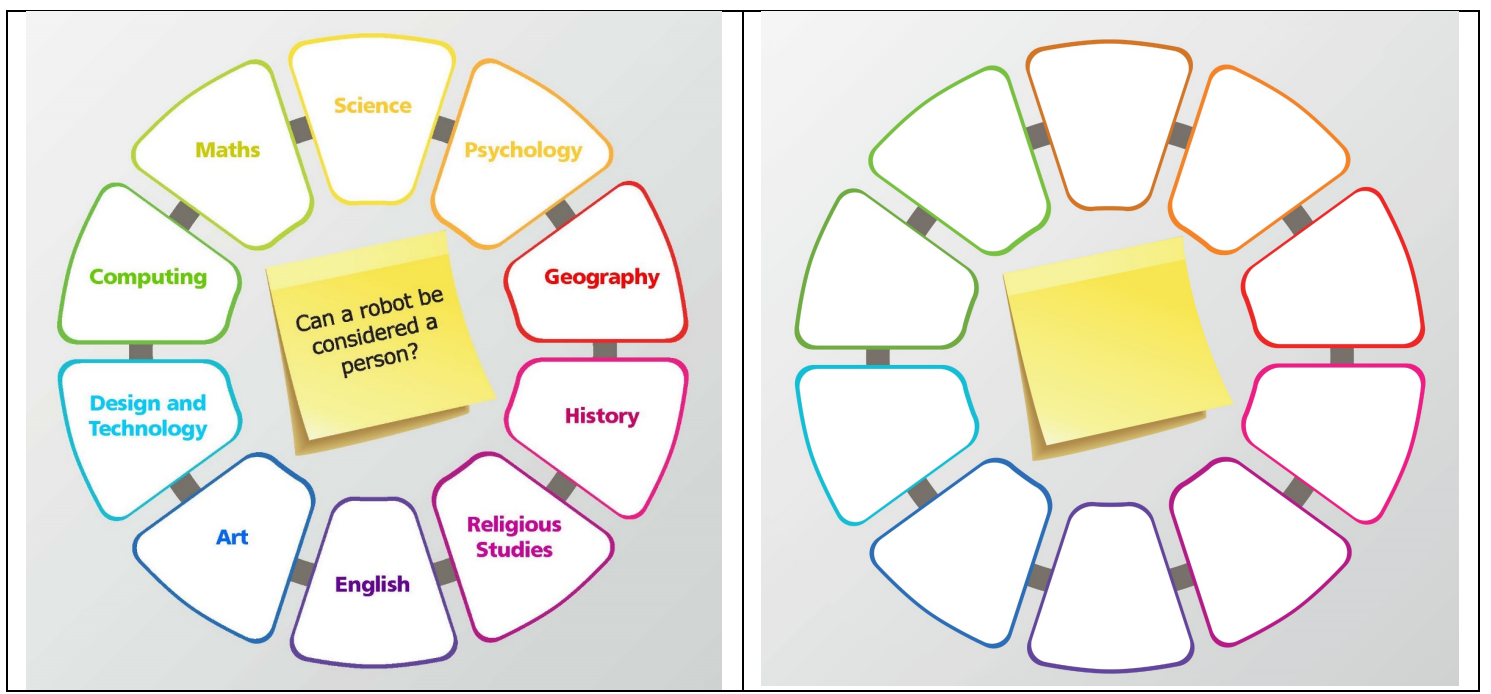

A simpler version of the wheel with fewer spaces for disciplines is also included in the resources we provide to schools. The idea is to explore a selected question through the lenses of each of a number of disciplines - noticing what they contribute and their strengths and limitations compared with other disciplines in the wheel. Students can also be given a selection of disciplines which they place into the wheel to indicate their perceptions of which subjects/disciplines are similar in terms of their preferred questions, methods and norms of thought. Disciplines that are perceived to be more closely related can be put into adjacent petals. Disciplines that seem to students to be 
very different and to address very distinctive areas of human knowledge can be put further apart on the wheel.

In further research we will be exploring the discipline wheel and other graphic tools as ways to prompt students and teachers to talk about the size of a question. A question that is framed to be addressed and answered scientifically using available equipment and within a lesson in a primary setting could be described as a smaller question than a cross-discipline question like, 'Why did the Titanic sink'. These indiscipline and cross-disciplinary questions appear to us in turn to be smaller than more complex questions like which charities should we support, why is there suffering in the world and was mathematics always present in the universe or did people invent it. Discussing the apparent size of a question can include analysing questions that students are encountering as part of their studies, questions that they generate themselves prompted by their experiences in and out of the classroom and also questions that are constructed by teachers to deliberately illustrate and compare questions of different size. This kind of epistemological analysis is currently missing from school education and yet in scholarship, it is widely said that working across more than one discipline is producing the most interesting and pertinent advances in knowledge today (Sandoval, 2016; Barnes, 2015; Byrne and Brodie, 2013; Kessel and Rosenfield, 2008; Ratcliffe et al., 2005; Rose, 2001). Our interest in this area was itself prompted by specialist research investigating students' capacities to explore Big Questions and their access to a range of views on the relationships between science and religion including positive views. The discipline wheel is a tool that presents science and religion to students in a format that provokes discussion and comparison rather than a presumption of a particular relationship. In further research we will 
explore what the tool reveals about students' capacities to discuss the natures of each

of the areas of enquiry they study, including the natures of science and religion.

\section{References}

Abrahams I. (2017) Minds-On Practical Work for Effective Science Learning. Science Education. Springer, 403-413.

Aikenhead G and Jegede O. (1999) Cross-Cultural Science Education: A Cognitive Explanation of a Cultural Phenomenon. International Journal of Research in Science Teaching 36: 269-287.

Astley J and Francis LJ. (2010) Promoting positive attitudes towards science and religion among sixth form pupils: dealing with scientism and creationism. British Journal of Religious Education 32: 189-200.

Atkins PW. (1995) The limitless power of science. In: Cornwell J (ed) Nature's imagination: The frontiers of scientific vision. Oxford: Oxford University Press, 122-132.

Author 1. (2004) PhD thesis.

Author 1. (2016) Journal paper. Science Education Journal.

Author 1 et al. (2013) Research paper. Research in Science Education.

Barnes J. (2015) Cross-curricular learning 3-14: Sage.

Barnes ME, Elser J and Brownell SE. (2017) Impact of a short evolution module on students' perceived conflict between religion and evolution. The American Biology Teacher 79: 104-111.

Bates S. (2006) Archbishop: stop teaching creationism. The Guardian.

Bell A. (2007) Designing and testing questionnaires for children. Journal of Research in Nursing 12: 461-469.

Berkman MB and Plutzer E. (2015) Enablers of doubt: How future teachers learn to negotiate the evolution wars in their classrooms. The ANNALS of the American Academy of Political and Social Science 658: 253-270.

Billingsley B. (2004) Ways of Approaching the Apparent Contradictions between Science and Religion. University of Tasmania.

Billingsley B. (2017) Teaching and learning about epistemic insight. School science review 98: 59-64.

Billingsley B and Hardman M. (2017) Epistemic insight and the power and limitations of science in multidisciplinary arenas. School science review 99: $16-18$

Billingsley B and Nassaji M. (2015) Ways to engage school students in big questions. Science and Religion: Celebrating the Dialogue and Exploring the Future. St John's College, Durham.

Billingsley B, Nassaji M and Abedin M. (2017) Entrenched compartmentalisation and students' abilities and levels of interest in science. School science review 99: 26-31.

Billingsley B, Nassji M, Fraser S, et al. (2018) A Framework for Epistemic Insight. Research in Science Education 48: 1115-1131.

Billingsley B, Taber KS, Riga F, et al. (2010) Teachers' perspectives on collaborative teaching about the 'Big Questions' in secondary schools: 
The silent treatment. Annual conference of the British Educational Research Association. Warwick.

Billingsley B, Taber KS, Riga F, et al. (2013) Secondary School Students' Epistemic Insight into the Relationships Between Science and Religion-A Preliminary Enquiry. Research in Science Education 43: 1715-1732.

Borgers N, De Leeuw E and Hox J. (2000) Children as respondents in survey research: Cognitive development and response quality. Bulletin of Sociological Methodology/Bulletin de Méthodologie Sociologique 66: 60-75.

Brooke JH. (1991) Science and Religion: Some Historical Perspectives, Cambridge: Cambridge University Press.

Byrne E and Brodie M. (2013) Cross Curricular Teaching and Learning in the Secondary School... Science: Routledge.

Dawkins R. (2006) The God Delusion, London: Bantam Press.

Deniz H, Donnelly LA and Yilmaz I. (2008) Exploring the factors related to acceptance of evolutionary theory among Turkish preservice biology teachers: Toward a more informative conceptual ecology for biological evolution. Journal of Research in Science Teaching 45: 420-443.

DfE. (2015) Science Programmes of Study, National Curriculum in England. In: Education Df (ed) May 2015 ed. London.

DfES. (2018) Schools pupils and their characteristics: January 2018 - main text. In: Education Df (ed). London, 1.

Erduran S, Kaya E and Dagher ZR. (2018) From Lists in Pieces to Coherent Wholes: Nature of Science, Scientific Practices, and Science Teacher Education. Science Education Research and Practice in Asia-Pacific and Beyond. Springer, 3-24.

Fensham PJ. (2016) The Future Curriculum for School Science: What Can Be Learnt from the Past? Research in Science Education: 1-21.

Foster C. (2013) Resisting reductionism in mathematics pedagogy. The Curriculum Journal 24: 563-585.

Fulljames P, Gibson HM and Francis LJ. (1991) Creationism, Scientism, Christianity and Science: a study in adolescent attitudes. British Educational Research Journal 17: 171 - 190.

Guessoum N. (2015) Understanding Qur anic Miracle Stories in the Modern Age By Isra Yazicioglu. Journal of Islamic Studies 26: 199-202.

Ha M, Haury DL and Nehm RH. (2012) Feeling of certainty: uncovering a missing link between knowledge and acceptance of evolution. Journal of Research in Science Teaching 49: 95-121.

Hanley P, Bennett J and Ratcliffe M. (2014) The Inter-relationship of Science and Religion: A typology of engagement. International Journal of Science Education 36: 1210-1229.

Hansson L and Redfors A. (2007) Physics and the Possibility of a Religious View of the Universe: Swedish Upper Secondary Students' Views Science \& Education 16: 461-478.

Holaday B and Turner-Henson A. (1989) Response effects in surveys with school-age children. Nursing Research.

Humphreys C. (2003) The Miracles of Exodus: A Scientist's Discovery of the Extraordinary Natural Causes of the Biblical Stories, San Francisco: Harper Collins.

Ibrahim B, Buffler A and Lubben F. (2009) Profiles of freshman physics students' views on the nature of science. Journal of Research in Science Teaching 46: 248. 
Kessel F and Rosenfield PL. (2008) Toward transdisciplinary research: historical and contemporary perspectives. American Journal of Preventive Medicine 35: S225-S234.

Konnemann C, Asshoff R and Hammann M. (2016) Insights Into the Diversity of Attitudes Concerning Evolution and Creation: A Multidimensional Approach. Science Education 100: 673-705.

Konnemann C, Höger C, Asshoff R, et al. (2018) A Role for Epistemic Insight in Attitude and Belief Change? Lessons from a Cross-curricular Course on Evolution and Creation. Research in Science Education: 1-18.

Kötter M and Hammann M. (2017) Controversy as a Blind Spot in Teaching Nature of Science. Science \& Education 26: 451-482.

Lederman NG, Antink A and Bartos S. (2014) Nature of science, scientific inquiry, and socio-scientific issues arising from genetics: A pathway to developing a scientifically literate citizenry. Science \& Education 23: 285-302.

Long R and Bolton P. (2018) House of Commons Library: Briefing paper: Number 06972, 6 June 2018: Faith Schools in England: FAQs.

Martin-Hansen LM. (2008) First-year college students' conflict with religion and science. Science \& Education 17: 317-357.

Murphy N. (2014) Mind, Soul, and the Cognitive Neurosciences. In: Fuller M (ed) The Concept of the Soul: Scienctific and Religious Perspectives. Newcactle upon Tyne: Cambridge Scholars Publishing, 39-55.

ONS. (2012) Religion in England and Wales 2011. London: Office for National Statistics.

Overton DT and Chatzichristodoulou M. (2010) The teaching of science through the performing arts. Procedia - Social and Behavioral Sciences 2: $3871-3875$.

Polkinghorne J. (2013) Science and Religion in Dialogue. The Boyle Lectures. St Mary-le-Bow, Cheapside Gresham College, 1-8.

Polkinghorne J, Hedley J and Chartres RJC. (2014) The Boyle Lectures: Science and Religion in Dialogue.

Ratcliffe M, Harris R and McWhirter J. (2005) Cross-curricular collaboration in teaching social aspects of genetics. Research and the Quality of Science Education. Dordrecht: Springer: Springer, 77-88.

Reich H. (1991) The role of complementarity reasoning in religious development. New Directions for Child and Adolescent Development 1991: 77-89.

Reiss MJ. (2013) Religion in science education: Theory and practice. In: Mansour N and Wegerif R (eds) Science education for diversity: Theory and practice. New York/Heidelberg: Springer.

Rose S. (2001) Moving on from old dichotomies: beyond nature-nurture towards a lifeline perspective. The British Journal of Psychiatry 178: s3s7.

Sanders M and Ngxola N. (2009) Addressing teachers' concerns about teaching evolution. Journal of biological education 43: 121-128.

Sandoval WA. (2016) Disciplinary insights into the study of epistemic cognition. Handbook of epistemic cognition: 184.

Schreiner P. (2000) Religious education in Europe. A collection of basic information about RE in European countries, Münster.

Shipman HL, Brickhouse NW, Dagher Z, et al. (2002) Changes in student views of religion and science in a college astronomy course. Science Education 86: 526-547. 
Smith MU. (2010) Current status of research in teaching and learning evolution: II. Pedagogical issues. Science \& Education 19: 539-571.

Smith MU and Scharmann L. (2008) A multi-year program developing an explicit reflective pedagogy for teaching pre-service teachers the nature of science by ostention. Science \& Education 17: 219-248.

Southgate C. (2011) God, Humanity and the Cosmos-: A Textbook in Science and Religion: Bloomsbury Publishing.

Stenmark M. (2001) Sceintism: Science, ethics and religion Aldershot: Ashgate Publishing Limited.

Taber KS, Billingsley B, Riga F, et al. (2011) To what extent do pupils perceive science to be inconsistent with religious faith? An exploratory survey of 13-14 year-old English pupils. Science Education International 22: 99-118.

Ward K. (2008) The big questions in science and religion, West Conshohocken, Pennsylvania: Templeton Foundation Press.

Wellman HM. (2014) Making minds: How theory of mind develops: Oxford University Press.

Wilkinson D. (2005) Hawking, Dawkins and The Matrix: science and religion in the media. In: Alexander D (ed) Can we be sure about anything? Science, faith and postmodernism. Leicester: Inter-Varsity Press, 214236. 